\title{
Strategic Analysis towards the Formulation of Micro Sourcing Strategic Trusts
}

\author{
Noor Habibah Arshad \\ Department of Information Systems \\ Faculty of Computer and Mathematical Sciences, \\ University Teknologi MARA, \\ Shah Alam, Malaysia
}

\author{
Siti Salwa Salleh, Syaripah Ruzaini Syed Aris, \\ Norjansalika Janom, Norazam Mastuki \\ Faculty of Computer and Mathematical Sciences, \\ Faculty of Accountancy University Teknologi MARA, \\ Shah Alam, Malaysia
}

\begin{abstract}
Malaysian government, realising its responsibility to upgrade the quality of life, has identified micro sourcing industry as one of the potential industry to elevate the livelihoods of the poor especially the B40 group. The B40 in Malaysia is defined as household income level of less than RM 2,300 per month. The huge potential impacts of micro sourcing industry provide motivation for this research. In determining the best way for Malaysia to implement micro sourcing industry using the available resources, strategic analysis was conducted. Tools such as SWOT and Gap analysis were used to perform the strategic analysis. Thus, the objective of the paper is to develop a full awareness of the situation through Strengths, Weaknesses, Opportunities and Threats (SWOT) analysis. In order to determine the factors that define its current state, gap analysis was used to list down the factors needed to reach the target state and to fill the gap between these two states. Through these analyses it helps with both strategic planning and decisionmaking. Workshops were held to gather information from stakeholders and to discuss on the internal Strength and Weakness and the external Opportunity and Threat of micro sourcing. The discussions reveal the gap between where we are and where we want to be and also reveal areas where it must improve to meet the micro sourcing goals. The findings from the SWOT and Gap analyses will provide perspective, will reveal connections, areas for action and also identify deficiencies. The analyses will also build on the strengths, minimize the weaknesses, seize opportunities and counteracts threats and fine tuning one process. Finally, micro sourcing strategic trusts will be formulated.
\end{abstract}

Keywords - micro workers; job providers; crowd sourcing; B40 group; SWOT analysis; Gap analysis

\section{INTRODUCTION}

In December 1996 the Malaysian National IT Agenda (NITA) was launched by the National IT Council (NITC). The Agenda provides the foundation and framework - known as the National IT Framework (NITF) - for the utilisation of ICT to transform Malaysia into a developed nation in its own mould consistent with Vision 2020 [1]. NITA's vision is to utilise ICT to transform Malaysian society into an information society, followed by a knowledge society and finally to a values-based knowledge society. NITA focuses on the development of people, info-structure and applications to create value, to provide equity and access to all Malaysians, and to qualitatively transform the society into a values-based

This study is conducted by researchers from Universiti Teknologi MARA, Shah Alam, Malaysia in collaboration with Malaysia Development Corporation (MDeC) and fully funded by Malaysia Ministry of Finance. knowledge society by the year 2020 [1].

One key strategy to transform the society into a valuesbased knowledge society is to elevate the livelihoods of the poor. With this strategy in mind, Digital Malaysia was established as an enabler towards a knowledge-based economy to drive wealth creation and enhance quality of life by harnessing and building upon Malaysia's varied ICT initiative [2]. Prime Minister of Malaysia also mentioned about Malaysia intention to build an ecosystem that promote the pervasive use of ICT in all aspect of the economy [3].

Under Digital Malaysia [4], micro sourcing industry has been identified as a potential industry to uplift the income of the population in the bottom 40 percent household income (B40). Involvement of B40 group in micro sourcing activities will allow them digital access and be paid for completing micro tasks. The household income level of the B40 is less than RM 2,300 per month [5]. Majority of these households have single income earners. More than half of the household's heads $(52 \%)$ have no recognised education background. With no education background, low skills level and in certain cases, living in remote locations, the B40 households are limited in their economic mobility and ability to secure higher paying jobs as well as income opportunities. Studies have also shown that there is low ICT adoption among poor communities in Malaysia, which is part of the B40 group [6].

The micro sourcing industry in Malaysia is still at its infancy stage and not properly structured [7]. There exists micro sourcing platforms but the number is relatively small and their roles are very limited, as mediator between demand (job providers) and micro workers (supply), and advertising tasks that are sourced from demand. Number of demand is also quite limited and concentrated within the private sector. The tasks available in the market are not targeted to any specific micro workers and these workers are given proper training to perform the task. The existing scenario could make the industry unsustainable in the long run.

Thus, the objectives of this paper are: (1) to come up with the positives and negatives of micro sourcing within the demand, supply and platforms (S-W) and outside of it, in the external environment (O-T), and (2) to present current situation and also highlighting the gaps exist that need to be filled. By developing a full awareness of the situation can help with both strategic planning and decision-making. 


\section{Micro SOURCING CURRENT SCENARIOS}

Micro sourcing is defined as "the art of taking a job traditionally performed by a designated agent (usually an employee) and outsourcing it to an undefined, generally large group of people in the form of an open call" [8]. In another word it is "to outsource a job to a large, anonymous crowd of workers, the so-called human cloud, in the form of an open call" [9]. When a task needs to be completed, it can be done faster and more efficiently with the help of others via micro sourcing. This is the fundamental understanding of what micro sourcing is from an employer's perspective. Micro sourcing has become a cost effective way for companies to give opportunities for individuals outside of the companies to use their skills and time for good use and earn additional income. These companies pay people based on the amount of hours of works, and save millions of ringgits by doing so. Companies also will be able to tap into a large pool of talents, allowing these talents to choose what works suit them best. Micro sourcing also allows companies to employ a large group of skilled people to handle projects within a specific time frame for a fixed price. Typical micro tasks are translation, data validation, image tagging, research, writing, editing, categorisation and data entry.

Some of existing micro sourcing platforms available globally supporting crowd-sourced micro tasks are AmazonMechanicalTurk, CrowdFlower, SamaSource, Ushahidi, Micro sourcing and ODesk. AmazonMechanicalTurk was launched in November 2005 and which the requestors are restricted to US-based entities, however the workers can be sourced globally [10]. CrowdFlower was founded in 2007 and uses the MTurk platform to distribute work, but provides its own interface on which work is completed. It also has sophisticated APIs to create and manage works [11]. SamaSource was founded in 2008 and claims to have a dedicated team of remote workers but does not post jobs on a public portal like Mturk [12]. Ushahidi was founded in 2008 and provides a platform for information collection, visualization and interactive mapping, especially for crises [13]. Micro sourcing is Philippines based company providing traditional outsourcing solutions [14]. Meanwhile, ODesk [15] was founded in 2003 and focus more on long-term work through remote staffing than real micro sourcing.

Global micro sourcing industry recorded substantial growth in the past few years [16]. The industry's Completed Task grew exponentially from 400,000 in 2008 to 291.8 million in 2011. The industry's total revenue meanwhile grew approximately $52.6 \%$ in 2010 and accelerated further to grow by $75 \%$ in 2011 . Internet Services contribute the largest share of micro sourcing industry's revenue, $29 \%$ of total industry's revenue, followed by Media and Entertainment (20\%) and Technology (18\%) sectors. While Manufacturing and Financial Services sectors have a relatively low share in of the industry's revenue at $13 \%$ and $8 \%$ respectively, these sectors present significant untapped opportunity for micro sourcing penetration in the future.
Demand in the global micro sourcing industry is driven by start-up and small companies. Collectively they account for over $60 \%$ of the market revenues. Start-up companies drive majority of the revenues in the industry, contributing $39 \%$ of the total revenues. Large enterprises with revenue of more than US\$1 billion represented only $8 \%$ of total job providers but contributed $21 \%$ of total revenues due to huge transaction volume [16].

It was also reported that [16], geographically, companies in North America and Europe are the largest job providers in the global micro sourcing industry, offering $90 \%$ of jobs collectively. Supply of workers are more diverse with North America provides the biggest number of workers, $45 \%$ of total workers, followed by Asia. Comparing the distribution of the job provider and the workers, Europe is the largest net job provider while Asia is the largest net supplier. Europe provides $36 \%$ of global micro sourcing jobs but supply only $18 \%$ of global micro sourcing worker. Asia meanwhile, provides $35 \%$ of the global workforce but only $7 \%$ of global micro sourcing jobs.

However, there is no data available on the number of job providers in local micro sourcing industry. To have an idea of the job providers' scenario in Malaysia, we use data available from a single platform case study by Human Capital Connection (YourPartTime.com)[17]. The traditional outsourcing industry in Malaysia is growing with number of jobs advertised and job providers increasing. As shown in Figure 1, number of job providers grew three-fold from 520 in 2009 to 2,400 in June 2012. Number of jobs advertised also grew three-fold from 619 to 3,000 in the same period. Figure 2 shows the value of job advertised. Based on value of jobs advertised in the period of January to June in 2012, 77\% of them are sourced from Small Medium Enterprises (SMEs), followed by multinational firms $(18 \%)$. The Government provided only $1 \%$ of total market.

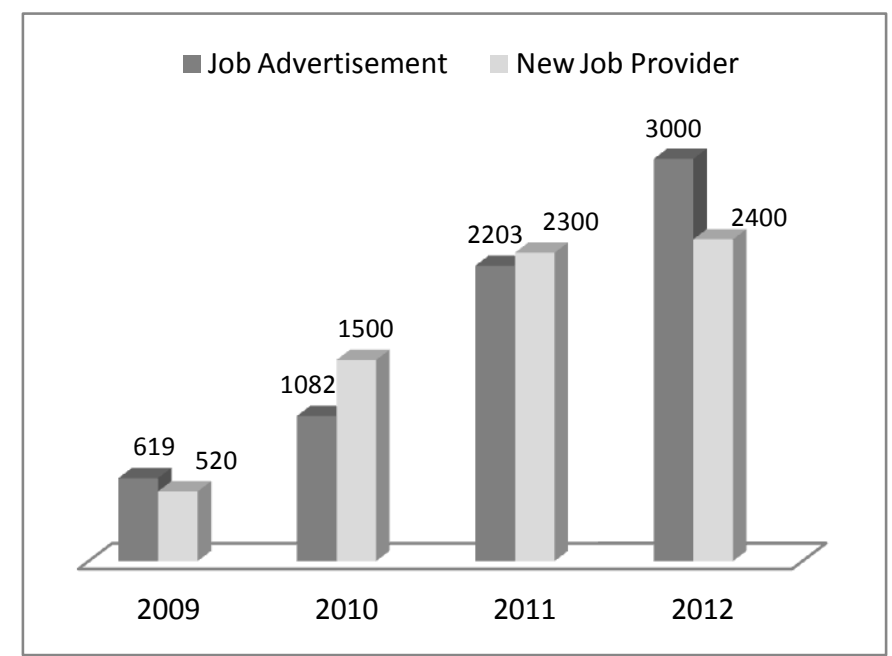

Fig. 1. Jobs Advertisement and Job Providers in Malaysian outourcing industry (2009 to June 2012) [17] 
Multinational $\square$ SME Government $\square$ Others

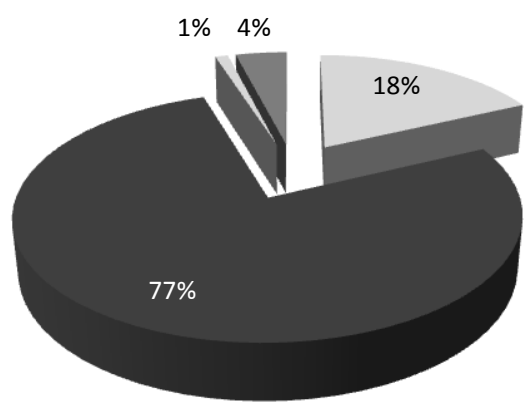

Fig. 2. . Malaysian outsourcing market share by Job Providers [17]

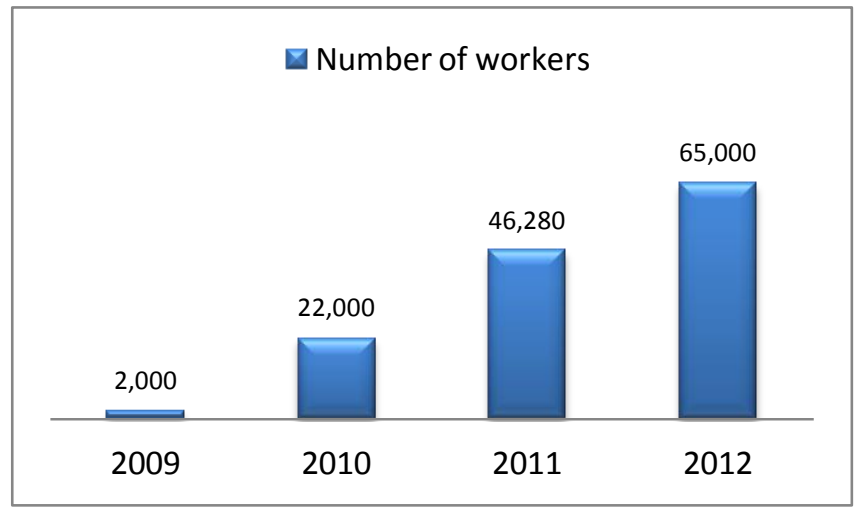

Fig. 3. Number of Malaysian micro workers [17]

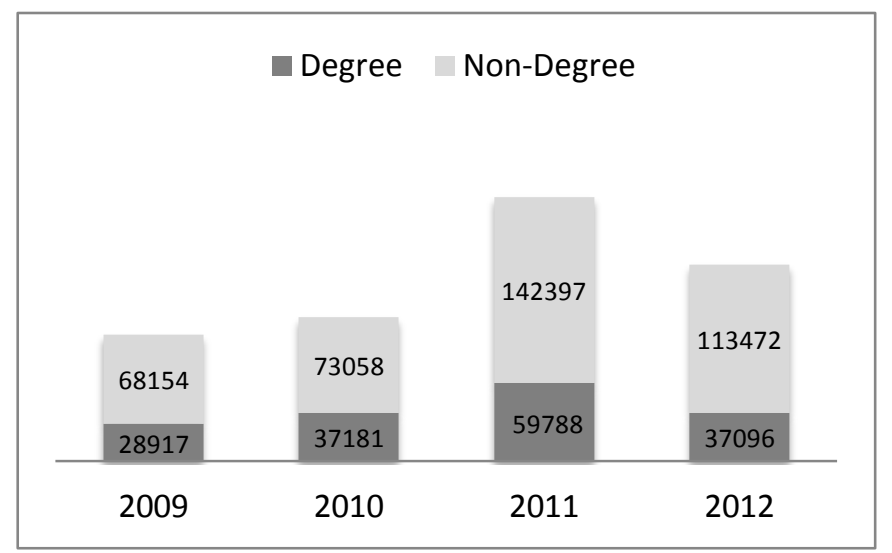

Fig. 4. Job placement by Job Malaysia for micro sourcing tasks [18]

The same as job providers, there is no comprehensive data on the number of micro workers in Malaysia. Thus, data from the same study by YourPartTime.com is used as proxy. Figure 3 showed that the number of micro workers in Malaysia is growing exponentially, in line with global trend. With initial number of 2,000 in 2009, the number increased to 22,000 in 2010, 46,280 in 2011 and 65,000 as at June 2012. This data is supported by increasing number of job placement for micro sourcing tasks by Job Malaysia [18] that showed similar trend as shown in Figure 4.

\section{METHODOLOGY}

Our first source of reference is documentation relating to micro sourcing and Digital Malaysia to understand the micro sourcing industry and the overall concept of Digital Malaysia. Two workshops were held to gather information from stakeholders and to discuss our initial findings for the study. The first workshop was held to gather information from stakeholders and to discuss on micro sourcing potentials, opportunities, potential growth and critical enablers from the perspectives of stakeholders. During the SWOT and Gap analysis, all stakeholders involved are asked to pool their individual and shared knowledge and experiences. Follow up interviews were done with some related government agencies and private sectors. The interviews help to uncover current practices, requirements and challenges in existing Malaysian micro sourcing environment. The second workshop was held to discuss the findings and recommendations on the micro sourcing strategic thrusts, framework, ecosystem and directions. Participants of both workshops were from Micro Sourcing for B40 Consultative Committee (MSCC), government ministries and agencies, Non-Governmental Organization NGOs) and private sectors. The information gathered from all these sources was then compiled and analysed as inputs for this paper.

\section{RESUlTS AND DisCUSSION}

Strategic Analysis using SWOT and Gap analyses have been conducted in order to achieve the desired and targeted results. Strategic trusts are formulated based on these analyses. Based on the analysis of the current scenario of local micro sourcing industry, detailed description of SWOT, GAP analyses of the current scenario of local micro sourcing industry are described below.

The SWOT and GAP analyses were to analyse the three groups involved in the micro sourcing. The first group is Demand who provide the tasks. The second group is Supply or Micro Workers who are the people who complete the micro tasks. The third group is the Malaysian Micro sourcing Platforms. The platforms are the software and processes to run micro works and micro sourcing projects for use with internal or external crowd. The workshop captured the four-cornered SWOT analysis that can be used to support in building the strengths, minimize the weaknesses, seize opportunities and counteract threats. Meanwhile, the Gap analysis highlighting the gap exists that need to be filled.

\section{1) SWOT Analysis}

Details of the findings are described below.

\section{A. SOWT Analysis - Job Provider (Demand)}

The results for SWOT Analysis for Job Providers are:

\section{a) Strengths}

- Existing government guidelines on Homeworking: Incentives to job providers: Digital Malaysia has identified micro sourcing as one of projects under the Social Dimension Thrust. Some incentives shall be 
available to induce local companies to outsource micro tasks especially those for B40 group. Public sector can also provide micro sourcing jobs such as digitisation of Government processes.

- Growing micro sourcing international market and demand. The global traditional outsourcing market size is estimated at be valued at US\$1.7 trillion. Malaysian outsourcing industry is predicted to be worth US\$1.9 billion by 2013, which include BPO, Systems Integration (SI) and IT Consulting.

\section{b) Weaknesses}

- Lack of awareness and low level of acceptance by local corporations:

Job Malaysia indicated that the awareness and acceptance by employers to employ micro workers are still low. There are only very few micro sourcing platforms that promote and stimulate the growth of the micro sourcing activities in Malaysia.

\section{c) Opportunities}

- Interest from socially responsible companies: Increasing number of "Triple" bottom line companies which focus on social, environment and financial results.

- Micro sourcing jobs from public sector: Amendment of procurement policies will promote micro sourcing jobs. Government procurement on supplies and services is very sizable, expected to be: RM14.2 billion and RM13.5 billion respectively in 2012 and 2013. Government jobs to be used as catalyst for demand although this should not pose additional cost to Government since it should reduce other labour costs.

- Regional market and OIC member countries market: Global micro sourcing market size was estimated at US $\$ 4.5$ billion in 2010 with 144,000 workers. The market size is estimated to grow to US\$20 billion in 2015 with 780,000 workers. Organization of Islamic Conferences (OIC) can also become a potential market to supply job for micro sourcing.

- Local SMEs (Over 600k): There are 645,136 SMEs that can be job providers for the micro sourcing industry. Most of these SMEs have already embrace ICT in their businesses.

\section{d) Threats}

- Quality and reliability of local micro workers: Many local firms have reservation on the quality and reliability of the tasks done by micro workers. These reservations can be summarised below:

- Will B40 be reliable?

- Will the quality of products and services provided meet expectation?

- Will the confidential data safe?

- Will the job delivered as the specified deadlines?
- Will there be enough supply of B40 with the right skill and attitude?

- Cheap foreign labour: Some local firms still prefer employing cheap foreign labour rather than exploring micro sourcing to keep costs low.

- Public sector procurement policy and process for crowd sourcing / micro sourcing activities: Government agencies are not willing or incapable of dividing jobs into micro tasking. They prefer to provide jobs to large contractors for simpler management.

\section{B. SWOT Analysis - Micro Workers (Supply)}

The results for SWOT Analysis for Micro Workers are:

\section{a) Strengths}

- Government support: Raising the living standards of low income household is one of the six National Key Result Areas (NKRAs). The Low income Households NKRA aims to completely eradicate hardcore poverty, reduce the incidence of poverty and enhance the productivity of low-income households.

- Existing guidelines for home working (JTKSM) can be extended to cover micro sourcing labour activities: Existing guidelines for home working under Department of Labour Peninsular Malaysia Ministry of Human Resources or Jabatan Tenaga Kerja Semenanjung Malaysia (JTKSM) can be applied to micro sourcing industry. Home working income such as income from micro works is exempted from income tax.

- Large potential workforce with access to basic ICT infrastructure: The B40 group was evenly distributed between urban and rural areas. Despite majority of rural household are self-employed, the main source of income is from paid employment. Total of $55 \%$ of urban B40 and $39.7 \%$ of rural B40 are salaried workers. These provide large potential workforce with some specific job related skills.

- Support from the Low Income Household NKRA to eradicate poverty: Data from the Ministry of Rural and Regional Development or Kementerian Pembangunan Luar Bandar dan Wilayah (KPLBW) shows that most of the B40 households have mobile phones. Some of them have PCs at home while those who do not own PC or have Internet connection are able to access Internet at community centres and cyber cafes. Therefore, most of the B40 households can participate in micro sourcing using mobile phones and PCs to communicate with micro sourcing platforms.

\section{b) Weaknesses}

- Majority of B40 with low level of education: Data from Department of Statistics (DoS) shows that most B40 households have low level education. In year 2009, $52.3 \%$ of people in the B40 group have no education certificate. Only $4.4 \%$ have post-SPM certificates (post high school certificates), while $25.4 \%$ and $17.9 \%$ have SPM (high school certificate) and PMR (lower school 
certificate) respectively as their highest education certificates. It will be quite a challenge to prepare them as micro workers.

- Most of B40 are low-skilled workers: Data from Human Capital Sdn. Bhd., Yayasan Basmi Kemiskinan (YBK) and Yayasan Pembangunan Islam Malaysia (YAPEIM) shows that the B40 group possesses moderate to low level skills. They have moderate competency in basic computer and mobile phone skills, and low competency in English, Internet skills, communication, financial management and multitasking.

- Most of B40 are low level in attitude: Feedback from Ministry of Rural and Regional Development or Kementerian Pembangunan Luar Bandar dan Wilayah (KPLBW) and Pusat Zakat Selangor (PZS) shows that the common personality or features of the B40 are that they display low level in attitude, internal motivation, and goal orientation. They also do not have a long-term goal, lacking internal focus; have low self-esteem and low motivation to get extra income or reward. They are not autonomous and do not like responsibility. They have moderate level of creativity, productivity and initiative. Many of them are not interested on getting and doing work to earn their living and prefer to receive financial assistance and aids from Government or relief agencies.

- Financial-related issue: A Focus group discussion highlighted the fact that the B40 group may be willing to use their own money in advance only if the amount is little (for example 5-10 ringgit for phone prepaid reload and this is also subject to the level of their socioeconomic background). The B40 may also be willing to join the micro sourcing work force if the income is attractive (RM100 and above).

- Low level of English proficiency to cater for International demand: Total of $52.3 \%$ of people in the B40 group have no education certificate and most of them have low to moderate competency in computer and Internet skills, as well as English proficiency.

\section{c) Opportunities}

- Flexible and income generation opportunity for the B40: Large range of tasks is available in the micro sourcing industry, which provides opportunities for the B40 group to participate in micro tasks provided by international firms.

- Opportunities to upgrade skills in industry-relevant areas: Opportunities to upgrade skills in industryrelevant areas by skills development centres such as Pusat Giat MARA, Jabatan Kemajuan Masyarakat (KEMAS) and community colleges. The B40 group also needs soft skills training in the area of Internet usage, words processing, spreadsheet, presentation software, web or blog development, basic communication skills, marketing skills, time management skills, platform training and motivational courses on self awareness and personal development.

- Availability of wide range of tasks in micro sourcing industry: Many parties can engage in activities to attract B40 into micro sourcing industry. Some of the activities are:

- Awareness campaigns such as road-shows.

- Reaching out to NGOs and community to support, motivate and gather feedback from existing and new micro workers.

- Masterminding and coaching to ensure continuous micro workers development.

\section{d) Threats}

- Inability if B40 micro workers to compete against skilled workers: Those not in B40 might compete with B40 in completing micro tasks, which could reduce the effectiveness of the Project.

\section{SWOT Analysis - SWOT Analysis - Platforms}

The results for SWOT Analysis for Platforms are:

\section{a) Strengths}

- Government support via the Digital Malaysia initiative: Under the Social Dimension Thrust, Digital Malaysia will look at infusing technology to uplift quality of life by spurring Netizens to move from digital consumption to digital production and also expanding digital access to all levels of society, especially the B40 group.

- Local platforms understand the B40 needs and issues: Some platforms have been working with B40 and understand their needs. With the support of Job Provider (Demand) and Community Champions, large range of tasks can be executed through micro sourcing.

\section{b) Weaknesses}

- Very basic functionality: There is no established national minimum standard to increase credibility of local platforms to both local and international markets. Certification program for micro sourcing platforms have yet to be created.

- Lack experience and exposure to international market: There is a lack of skilled/ experienced human resources to support micro sourcing platforms. There is no structured program to promote growth of local platforms. Specialised project management and business development teams are needed to promote and market micro sourcing solutions.

- Very basic micro business model: Currently, micro tasks advertised are selected directly by micro workers. There is no auto mechanism to ensure that micro tasks are selected by the most suitable micro workers.

- Weak payment mechanism: Payment for completed micro tasks is directly from organisation to micro workers. This mechanism creates issues such as guarantee of payment to be received by the workers. A 
better mechanism is needed to ensure micro workers receive payment for tasks completed.

- Lack of escrow account functionality: Currently, job provider pays the imbursement directly to workers. In ability to ensure more secure environment in the payment mechanism, escrows account functionality should be introduces.

\section{c) Opportunities}

- Collaboration with established international platforms/ players: There is potential to develop various specialisation and niche area micro sourcing platforms catering for local and regional micro workers. Local platforms can collaborate with establish international platforms such as Samasource and Crowdflower.

- Leveraging on cloud computing technologies and solutions: MSC status companies offer cheap cloud computing resources which enable low operating cost for micro sourcing platforms players. The low operating cost will make Malaysian platforms competitive in international market.

- New model/ localized platforms for local, regional market needs: International micro sourcing platforms might not be suitable for the local micro workers especially the B40 group. A unique platform can also be attractive for new job providers, local and international.

- E-working opportunities: Malaysia has among the highest internet penetration with $89 \%$ of the population are internet users, based on data as at July 2012. This data shows the potential huge pool of micro workers for local micro sourcing platforms.

\section{d) Threats}

- Acceptance by local market as international platforms are more established and experience: International platforms are more efficient and have more experience, which will provide great competition for local platforms.

- Cyber security issues including online scams/ fake platforms:

Occurrences of cybercrime-have instilled fear and lacked of confidence with ICT platforms. Lack of motivation and attitude problem of B40 workers-might make them not interested to new type of income generating jobs.

The SWOT analysis which focuses on the four elements which are the strengths, weaknesses, opportunities and threats are able to address or at least recognized the full situation of micro sourcing in Malaysia. Furthermore, this analysis could be a source of micro sourcing strategic planning where it helps to identify core competencies and setting up the objectives for strategic planning.

\section{2) GAP Analysis}

The Gap analysis shows the present situation and also highlighting the gaps exist that need to be filled.

\section{A. Gap Analysis - Job Providers (Demand)}

The results for Gap Analysis for Job Providers are:

a) Local Market - Lack of awareness and low industry acceptance

In general, awareness and acceptance by employers to employ micro workers are still low either because of lack of knowledge about the industry or lack of trust on local platforms. These issues have to be mitigated by awareness programs and proper governance in the industry.

\section{- Public Sector}

The Government provides only $1 \%$ of the total jobs in local traditional outsourcing industry. The share of outsourced jobs from the Government should be increased via its procurement policies, tapping into Government's expenditure on supplies and services that range between RM10 billion to RM15 billion a year. These outsourced jobs can be break down as micro tasks such as archive digitisation and e-Government related.

\section{- Private Sector}

Even though SMEs contribute $77 \%$ of total jobs provided in local traditional outsourcing industry, there are still lots of potential that can be tapped especially in micro sourcing. In 2010 [19], 97.3\% of 645,136 registered companies are categorised as SMEs as shown in Figure 5. $90 \%$ of these SMEs are in the services sector, $6 \%$ in the manufacturing sector, while the remaining in construction, agriculture and mining sectors. In the services sector, SMEs mainly operate in distributive trade subsector (wholesale and retail trade services).

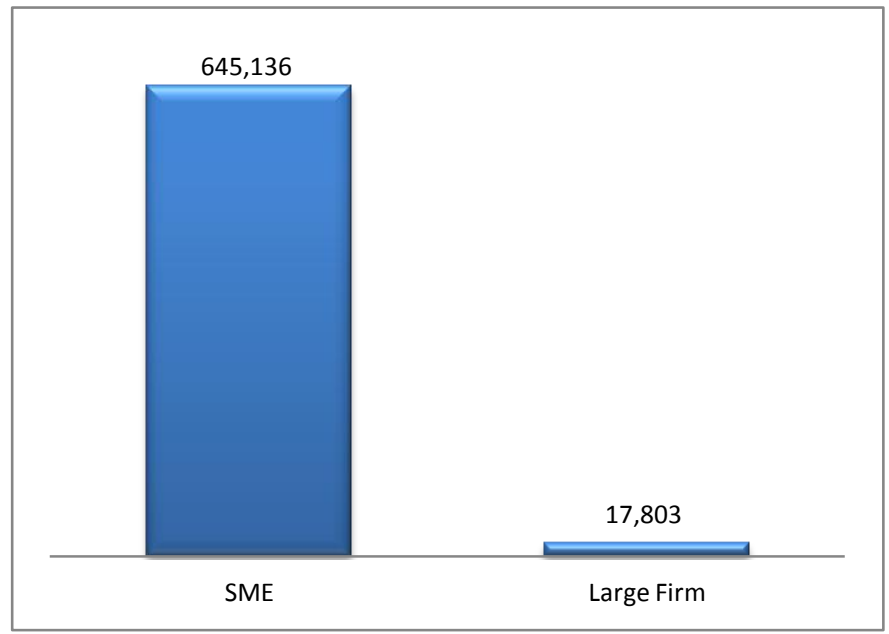

Fig. 5. Registered companies in Malaysia in 2010 [19]

SMEs have also contributed significantly to the Malaysian economy.

Figure 6 shows that SMEs have consistently contributed more than $65 \%$ of total private sector's value added to the Malaysian GDP every year 


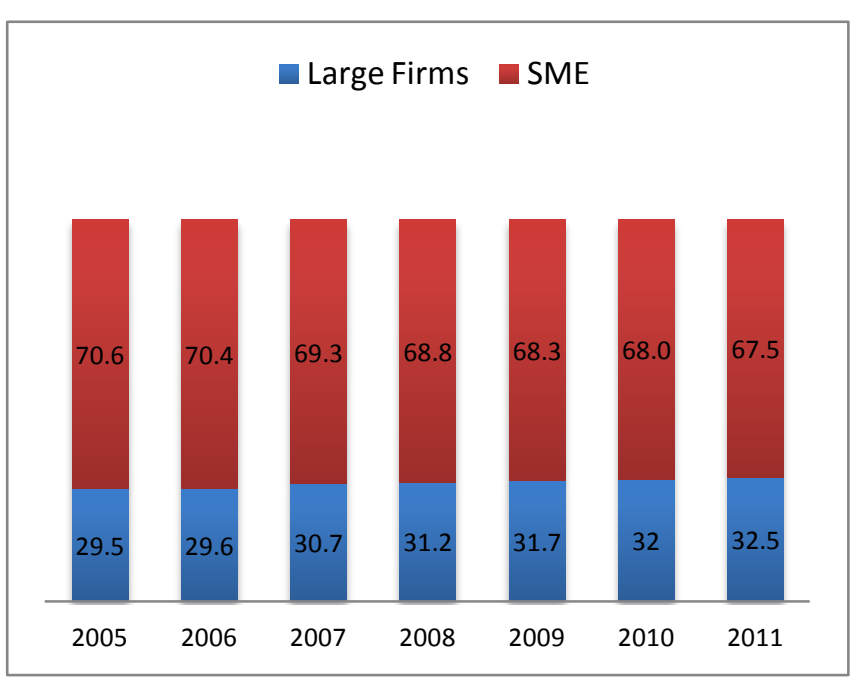

Fig. 6. Private sector's value added to Malaysian GDP [19]

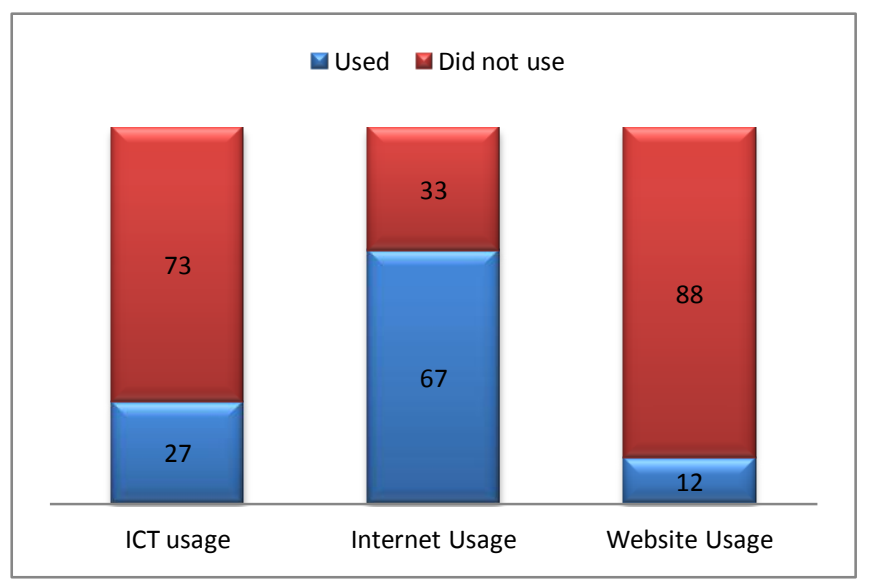

Fig. 7. ICT usage by SMEs [19]

Even though SMEs are main provider of outsourcing jobs, usage of ICT by SMEs is still low in Malaysia. Currently, only $25 \%$ of SMEs uses ICT in their businesses and only $12 \%$ of them have their own websites as shown in Figure 7. The usage however, is expected to grow as Google Malaysia, in partnership with MCMC, has launched the Get Malaysian Business Online (GMBO) campaign, a new initiative to bring more Malaysian businesses online. Google Malaysia will invest up to RM10 million to help 50,000 local SMEs set up their websites [19]. These new ICT users should be tapped as job providers for micro sourcing industry. There is also a need to increase awareness among the SMEs of the potential of lower operating costs with micro sourcing.

Other than SMEs, large firms should also be encouraged to provide jobs in micro sourcing industry especially in ITrelated tasks. Socially responsible companies can also be roped in to provide micro works especially to targeted micro workers.
A case study was conducted to identify local companies that currently outsource some of their tasks and their potential involvement as job providers in micro sourcing industry. The study's findings are summarised in the Table 1.

TABLE I. CASE Study's Findings: Potential LocAl Job PROVIDERS

\begin{tabular}{|c|c|c|c|c|c|}
\hline & $\begin{array}{c}\text { HR } \\
\text { Company }\end{array}$ & $\begin{array}{c}\text { IT } \\
\text { Services } \\
\end{array}$ & $\begin{array}{c}\text { IT } \\
\text { Consultant } \\
\end{array}$ & $\begin{array}{c}\text { FM } \\
\text { Radio } \\
\end{array}$ & $\begin{array}{c}\text { Telco } \\
\text { Berhad }\end{array}$ \\
\hline \multicolumn{6}{|c|}{ EXISTING OUTSOURCED TASKS } \\
\hline $\begin{array}{l}\text { Out- } \\
\text { sourced } \\
\text { Task }\end{array}$ & $\begin{array}{l}\text { Payroll, } \\
\text { Allowance, } \\
\text { Travelling } \\
\text { claims, } \\
\text { Leaves, } \\
\text { Medical. }\end{array}$ & $\begin{array}{l}\text { Multi- } \\
\text { media. } \\
\text { Creative, } \\
\text { Data } \\
\text { entries, } \\
\text { Tedious } \\
\text { repetitive } \\
\text { works. }\end{array}$ & $\begin{array}{l}\text { All areas } \\
\text { which are } \\
\text { not their core } \\
\text { expertise }\end{array}$ & $\begin{array}{l}\text { Sales } \\
\text { promoter } \\
\text { in each } \\
\text { state }\end{array}$ & $\begin{array}{l}\text { Application } \\
\text { Support \& } \\
\text { Infra- } \\
\text { structure } \\
\text { Services }\end{array}$ \\
\hline Costs & $\begin{array}{l}1.2 \\
\text { million } \\
(\mathrm{RM}) \text { per } \\
\text { year }\end{array}$ & $\begin{array}{l}10 \mathrm{~K} \\
(\mathrm{RM}) \text { to } \\
500 \mathrm{~K} \\
(\mathrm{RM}) \text { per } \\
\text { project }\end{array}$ & $\begin{array}{l}1 \text { million to } \\
2 \text { million } \\
(\mathrm{RM}) \text { a year }\end{array}$ & $\begin{array}{l}\text { No } \\
\text { amount } \\
\text { revealed }\end{array}$ & $\begin{array}{l}\text { About } 10 \\
\text { million } \\
(\mathrm{RM}) \text { per } \\
\text { month }\end{array}$ \\
\hline $\begin{array}{l}\text { Local/ } \\
\text { Off- } \\
\text { shore }\end{array}$ & Local & Local & $\begin{array}{l}\text { Development } \\
\text { is done } \\
\text { offshore }\end{array}$ & Local & $\begin{array}{l}\text { Mostly } \\
\text { local }\end{array}$ \\
\hline \multicolumn{6}{|c|}{ POTENTIAL MICRO SOURCING TASKS } \\
\hline $\begin{array}{l}\text { Area } \\
\text { Out- } \\
\text { sourced }\end{array}$ & $\begin{array}{l}\text { All IT- } \\
\text { related }\end{array}$ & Mainly IT & $\begin{array}{l}\text { Only IT- } \\
\text { related. }\end{array}$ & $\begin{array}{l}\text { Technical } \\
\text { area }\end{array}$ & $\begin{array}{l}\text { IT-related } \\
\text { \& Infra- } \\
\text { structure } \\
\text { Services }\end{array}$ \\
\hline $\begin{array}{l}\text { Potential } \\
\text { for Micro } \\
\text { sourcing }\end{array}$ & $\begin{array}{l}\text { Hosting of } \\
\text { server and } \\
\text { messaging }\end{array}$ & $\begin{array}{l}\text { Clerical } \\
\text { task }\end{array}$ & $\begin{array}{l}\text { IT } \\
\text { Maintenance } \\
\text { and printing } \\
\text { documents } \\
\text { nationwide }\end{array}$ & \begin{tabular}{|l|} 
No \\
specific \\
task \\
identified
\end{tabular} & $\begin{array}{l}\text { Application } \\
\text { Support, } \\
\text { Trans- } \\
\text { formation } \\
\text { Project, } \\
\text { Infra- } \\
\text { structure } \\
\text { Services }\end{array}$ \\
\hline
\end{tabular}

\section{b) International Market}

The global outsourcing market as shown in Figure 8 is expected to grow at a CAGR of $4.31 \%$ from 2010 to 2015. By 2015, the market is estimated to reach US\$574 billion, with Information Technology Outsourcing (ITO), which comprises both Application Outsourcing and Infrastructure outsourcing, accounting for US\$363 billion, and BPO at US\$211 billion in revenue [20].

Malaysia should leveraged on the expected growth in global micro sourcing industry especially Impact Sourcing. Malaysia with its diverse population with multicultural background should be promoted as a regional micro sourcing hub to attract international firms outsourcing their micro tasks in Malaysia. 


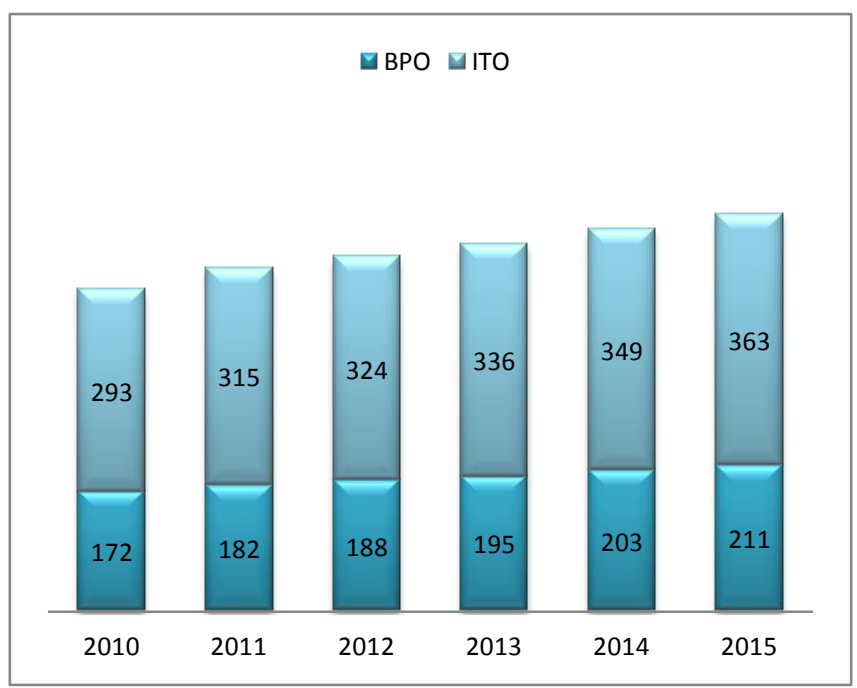

Fig. 8. Global outsourcing market (US\$ Billion) [20]

According to the Monitor Group [21] the following trends will drive the growth of the Impact Sourcing market in the coming years:

- The increasing reach and decreasing cost of telecommunications is expanding the list of countries and regions that can compete for outsourcing work;

- There is continuing pressure on corporations and, to some extent, Governments to deliver services, particularly non-core services, in a cost effective manner;

- There is increasing demand for the digitisation of nondigitised records across the private and public sectors;

- There is an increasing level of Government activity that lends itself to outsourcing tasks, such as archive digitisation, the growth of e-Government platforms and universal identity number projects; and

- There exists latent demand for tasks such as data management, content editing and low-end transcription from large global companies.

A study by Accenture shows that companies in Asia Pacific are more likely to participate in Impact Sourcing. The study also shows that companies are willing to allocate $25 \%$ of their overall outsourcing portfolio for Impact Sourcing especially in Application Outsourcing and BPO. The study also highlighted barriers that prevent companies from considering Impact Sourcing which are Security, Language and Skills Availability, Infrastructure/ Technology Reliability, and Experience. Thus, these barriers need to be handled to attract micro sourcing jobs from international market.

\section{B. Gap Analysis - Micro Workers (Supply)}

The results for Gap Analysis for Micro Workers are:

\section{a) Attitude and motivation of $B 40$}

The most glaring gap on the supply side of the micro sourcing industry is the quality of the micro workers. While majority of micro workers in the international market are welleducated, the targeted micro workers under this Project are from the B40 group where majority of them have no education certificate. The B40 group also have low to moderate skill levels in basic computer and mobile phone skills as well as English and communication skills. In addition, most of the B40 group display low level in attitude, internal motivation, and goal orientation.

Therefore, trainings to improve the education and skills level of the B40 group to handle micro tasks is utmost important. There is a need to rope in NGOs, foundations and individuals as Community Champions to engage with these communities and provide support to help them embrace the micro sourcing industry.

Types of training for these micro workers should also suit the types of tasks that are suitable to them. Some of micro sourcing tasks that are available and might be suitable for the B40 are:

- Data Gathering

- Gathering price watch data

- National population census taking

- Promotional Services

- Positive word-of-mouth on social networking

- Back Office

- Data entry

- Data processing

- ICT and Internet related

- Web development

- Search engine optimisation

- Creative Services

- Web design

- Graphic design

- Advertisement design

- Language-related services

- Customer support

- Telemarketing

- Transcription

b) Language proficiency

$52.3 \%$ of people in the B40 group have no education certificate and most of them have low to moderate competency in computer and Internet skills, as well as English proficiency

\section{Gap Analysis - Platforms}

The results for Gap Analysis for Platforms are:

\section{a) Very basic functionality}

Existing micro sourcing platforms in Malaysia have limited roles [22]. For example, they advertise micro tasks to micro workers but do not take the role of matching the tasks to the most suitable and able micro workers. Analysis of existing platforms has revealed the following:

- Platforms act only as mediator

A platform receives a task from a job provider and advertises the task to micro sourcing workers. Once the micro sourcing workers agree to accept the task, the platform will introduce the job provider and the micro workers.

- Platforms do not have auto matching mechanism 
Once a task is advertised, it will be selected by micro workers. There is no mechanism to ensure that the micro workers are the most suitable and able workers to complete the task.

\section{- Platforms are not responsible for payment to micro} workers

Payments for completed tasks are made directly from job providers to micro workers. Some issues might arise from this arrangement such as guarantee of payment to be received by the workers. Therefore, there should be a mechanism to ensure that the payment is successfully received by the micro sourcing workers.

\section{- Platforms lack of credibility and reliability}

Platforms must ensure that tasks to be completed are properly executed by the micro workers. They must have mechanism to ensure the quality of the tasks completed.

\section{b) Early stage models}

To compete with international platforms and strengthen the local micro sourcing industry, local platforms' roles have to be expanded with well-established international platforms made as benchmark. As this Project is targeted to raise income of B40 group, platforms created must be well diverse and have niche/ focus areas to cater for targeted groups.

Strengthening and widening platforms' roles requires skilled/ experienced talents, and specialised project management and business development teams. Currently, there might not be enough local human resources to cater for this need. A strategy is required to attract and develop these talents.

\section{3) Strategic Thrusts}

Based on the strategic analysis, five strategic thrusts have been identified. The Strategic Thrusts are [23]:

a) Strategic Thrust 1: Harnessing Demand Side (Job Providers) of Domestic and International Market; Building,

b) Strategic Thrust 2: Platform Capacity and Capability

c) Strategic Thrust 3: Leverage and Utilise Existing Infrastructure;

d) Strategic Thrust 4: Uplift and Enhance Capability of the Supply Side (Micro Workers); and

e) Strategic Thrust 5: Instruments to Expedite Growth of Local Micro sourcing Industry.

These five Strategic Thrusts have been identified as the foundation for the Strategic Framework of the micro sourcing industry development in Malaysia. The rationale behind the Strategic Framework is to create micro sourcing Ecosystem [24] by narrowing or eliminating the gaps identified previously. The development of a complete Micro sourcing Ecosystem is to ensure industry sustainability and participation of B40 micro workers in an organised way. Success of the Ecosystem relies on effective roles played by the relevant stakeholders.

\section{CONCLUSION}

In general, awareness and acceptance by employers to employ micro workers are still low either because of lack of knowledge about the industry or lack of trust on local platforms. To compete with international platforms and strengthen the local micro sourcing industry, local platforms' roles have to be expanded with well-established international platforms made as benchmark. As this research is targeted to raise income of B40 group, platforms created must be well diverse and have niche/focus areas to cater for targeted groups. Strengthening and widening platforms' roles requires skilled/experienced talents, and specialised project management and business development teams.

Currently, there might not be enough local human resources to cater for this need. This is due to the majority of the targeted micro workers under this research are from the B40 group where majority of them having no education certificate. The B40 group also has low to moderate skill levels in basic computer and mobile phone skills as well as English and communication skills. In addition, most of the B40 group displays low level in attitude, internal motivation, and goal orientation. Therefore, trainings to improve the education and skills level of the B40 group to handle micro tasks is utmost important.

As a new industry, a strategic directions and guideline implementation need to be formulated. Therefore, the five strategic trusts formulated will be the foundation for the Strategic Framework of the micro sourcing industry development in Malaysia. The proposed framework is designed to ensure that the micro sourcing industry development will benefit all levels of society especially the B40 group. Although any individuals can become a micro worker, the opportunity to become micro workers should be targeted at B40 group with basic ICT knowledge and people outside the traditional workforce who want to increase their income.

The strategy is not only to attract and develop talents but also could leverage on the expected growth in global micro sourcing industry. With this right strategy and planning, Malaysia with its diverse population with multicultural background could be promoted as a regional micro sourcing hub to attract international firms outsourcing their micro tasks in Malaysia.

\section{REFERENCES}

[1] National IT Agenda - NITA. Retrieved Oct 2, 2012, from http://nitc.mosti.gov.my

[2] Prime Minister of Malaysia, 19 Oct 2011. Retrieved Oct 1, 2012, from http://www.mosti.gov.my/index.php?option=com_content\&view=article \&id=1778\%3A19-october-2011-pm-chairs-23rd-icm-and-14th-mscmsia-iap-meetings\&Itemid=64\&lang=en

[3] New York, 17 May 2011, Digital Malaysia programme on track. $\begin{array}{llll}\text { Retrieved Oct } & \text { 2012, from }\end{array}$ http://www.btimes.com.my/Current_New...cle/index_html

[4] Multimedia Development Corporation (MDeC). 2012. Digital Malaysia Lab Report.

[5] Economic Planning Unit, 2010, Tenth Malaysia Plan 2011-2015. EPU. Prime Minister's Department, Putrajaya 
[6] Nair, M and Vaithilingam, S. 2012. Innovative Use of ICT Among Urban-poor Communities: Challenges and Opportunities. ICT Strategic Review 2012/13 Innovation fo Digital Opportunities, pp 182-191.

[7] Arshad, N. H., Salleh, S.S., Aris, S.R.S, Janom, N., Mastuki, N., "Micro sourcing: The SWOT analysis on the demand, supply and platform". Science and Information Conference (SAI), October, London, 2013, pp. 768-773.

[8] Howe, J. (2006, June 2). Crowdsourcing: a definition. Wired Blog Network: Crowdsourcing. Retrieved Oct 1, 2012, from http://crowdsourcing.typepad.com/cs/2006/06/crowdsourcing_a.html

[9] Hoßfeld, T., Hirth,M.,and Tran-Gia, P. (2011) Modeling of Crowdsourcing Platforms and Granularity of Work Organization in Future Internet. Proceedings of the 2011 23rd International Teletraffic Congress (ITC 2011) p.142-149.

[10] AmazonMechanicalTurk, (accessed 29 Septembrer 2012), https://www.mturk.com/mturk/.

[11] CrowdFlower, (accessed 29 September 2012), http://crowdflower.com/.

[12] SamaSource, (accessed 29 September 2012), http://samasource.org/.

[13] Ushahidi , (accessed 29 September 2012), http://www.ushahidi.com/).

[14] Micro sourcing, (accessed 29 September 2012), http://www.micro sourcing.com/.

[15] ODesk, (accessed 29 September 2012), https://www.odesk.com/

[16] Crowd Sourcing Industry Report, Market Trends, Composition and Crowdfunding platform, 2012.
[17] Human Capital Connection (YourPartTime.com), 2012 (unpublished document)

[18] Jobs Malaysia, 2012, Kementrian Sumber Malaysia (unpublished document)

[19] SMECorp, 2012, Google to invest RM10mil to Help SMEs to Set Up Websites URL (accessed 19 February 2013), http://www.smecorp.gov.my

[20] Gartner Forecast Analysis, 2012, Forecast Analysis: IT Outsourcing, Worldwide, 2010-2015, 4Q11 Update

[21] Parikh, K. 2012, Impact Sourcing: Transforming Global Sourcing into a Social-Economic Endeavor. URL (accessed 21 December 2012), http://www.globalizationx.com/impact-sourcing-transforming-globalsourcing-into-a-socio-economic-endeavor-2/

[22] Syaripah Ruzaini Syed Aris, Norjansalika janom, Noor Habibah Arshad, Siti Salwa Salleh, Norazam Mastuki., "A Preliminary Study for Crtical Success Factors of Micro Sourcing in Malaysia". $3^{\text {rd }}$ International Conference on Research and innovations in Information Systems, 2013 (ICRIIS'13). "in-press".

[23] Arshad, N. H., Salleh, S.S., Aris, S.R.S, Janom, N., Mastuki, N., "Micro sourcing: Micro Sourcing Strategic Framework for Low Income Group International Journal of Advanced Computer Science and Applications, 2013, Vol. 4, No. 6, pp. 97-105.

[24] Salleh, S.S., Arshad, N. H., Aris, S.R.S, Janom, N., Mastuki, N., "Formulating Cohesive Digital Ecosystem of Micro Sourcing Business Process in Malaysia". Science and Information Conference (SAI), October, London, 2013, pp. 321-327. 